\title{
Love-iathan, the meat-whale and hidden people: ordering Faroese pilot whaling
}

\author{
Benedict E. Singleton ${ }^{1}$ \\ Örebro University, Sweden
}

\begin{abstract}
A key question in any environmental dispute is the nature of what is under discussion. 'Cosmopolitics' political battles over the form of reality - are a feature of many environmental clashes. This article focuses on one such clash: during the summer of 2014, grindadráp - the iconic practice of driving pilot whales for meat - was the big news item in the Faroe Islands. More accurately, a conservation campaign by the controversial group Sea Shepherd Conservation Society (SSCS), Operation Grindstop 2014, garnered most attention. Aiming to stop or at least disrupt the 'barbaric' and 'sadistic' grindadráp, SSCS were involved in several confrontations with Faroese authorities and publicly engaged with Faroese prowhaling advocates in several discussions that were seemingly fruitless. Based on 3 months fieldwork during the campaign, this article describes a 'political ontology' of Grindstop 2014. What emerged was a 'hybrid' born of a clash between two fundamentally dissonant systems of ordering, which structured and were reinforced by various practices, both discursive and material. Activists on both sides were engaged in a cosmopolitical struggle to decisively enact their orderings, creating alternative stories of whales, Faroese whaling, the ocean environment and modernity. The aim is to understand what happened when these orderings met. This article argues that throughout the summer these two orderings moved apart, consequently hiding the diversity of opinion and discussion within Faroese society around grindadráp. As such, alternative orderings of grindadráp were suppressed, notably those voiced by Faroese activists arguing that the practice should cease because of the high levels of toxins in pilot whale meat.
\end{abstract}

Key words: Faroe Islands, whaling, political ontology, cosmopolitics

\section{Résumé}

Une question clé dans un conflit environnemental est la nature de ce qui est en cours de discussion. «Cosmopolitique» - les batailles politiques sur la forme de la réalité - sont une caractéristique de nombreux affrontements environnementaux. Cet article se concentre sur un tel choc: au cours de l'été 2014, grindadráp - la pratique emblématique de la conduite des baleines pilotes pour la viande - a été le grand élément de nouvelles dans les îles Féroé. Plus précisément, une campagne de conservation par le groupe controversé Sea Shepherd Conservation Society (SSCS), Opération Grindstop 2014, a recueilli plus d'attention. Visant à arrêter ou au moins perturber le grindadráp «barbare» et «sadique», SSCS ont été impliqués dans plusieurs confrontations avec les autorités des îles Féroé et engagé publiquement avec les défenseurs pro-chasse à la baleine féroïens dans plusieurs discussions qui étaient apparemment stériles. Sur la base de trois mois sur le terrain pendant la campagne, cet article décrit une «ontologie politique» de Grindstop 2014. Ce qui est ressorti était un «hybride» né d'un affrontement entre deux systèmes fondamentalement dissonantes de commande, qui structurait et ont été renforcés par diverses pratiques, à la fois discursive et matériel. Les militants des deux côtés ont été engagés dans une lutte cosmopolitique à adopter de manière décisive leurs ordonnancements, créant d'autres histoires de baleines, la baleine féroïen, l'environnement de l'océan et de la modernité. Le but est de comprendre ce qui est arrivé lorsque ces ordonnancements se sont rencontrés. Cet article soutient que tout au long de l'été, ces deux ordonnancements écartés, cachant la diversité des opinions et la discussion au sein de la société féroïen autour de grindadráp. En tant que tel, d'autres ordres de grindadráp ont été supprimées, notamment celles exprimées par les militants férö̈ens en faisant valoir que la pratique devrait cesser en raison des niveaux élevés de toxines dans la viande de baleine pilote.

Mots clés: Îles Féroé, chasse à la baleine, l'ontologie politique, cosmopolitique

\footnotetext{
${ }^{1}$ Benedict E. Singleton, PhD Student in Sociology, School of Humanities, Education and Social Sciences, Örebro University, Sweden. Email: ben.singleton "at" oru.se. The research was supported by funds from the Vega Fond of Svenska Sällskapet för Antropologi och Geografi and by a travel scholarship from Fróðskaparsetur Føroya. Tacker till RL, FG och MT.
} 


\begin{abstract}
Resumen
Una cuestión clave en cualquier disputa ambiental es la naturaleza de lo que está en discusión. La "Cosmopolítica" -batallas políticas sobre la forma de la realidad- es una característica de muchos choques ambientales. Este artículo se centra en uno de esos choques: durante el verano de 2014, grindadráp - la práctica icónica de conducir ballenas piloto para el consumo de su carne - fue la gran noticia en las Islas Feroe. Específicamente, una campaña de conservación por el polémico grupo Sea Shepherd Conservation Society (SSCS), Operación Grindstop 2014, obtuvo la mayor atención. Con el objetivo de detener o al menos interrumpir el grindadráp 'bárbaro' y 'sádico', SSCS se vieron involucrados en varios enfrentamientos con las autoridades de las Islas Feroe y llevaron a cabos varios encuentros públicos con grupos favorables a los balleneros las Islas Feroe en varias discusiones que resultaron infructuosos. Sobre la base de tres meses de trabajo de campo durante la campaña, este artículo describe una "ontología política 'de Grindstop 2014. Lo que surgió fue un" híbrido "que nace de un choque entre dos sistemas fundamentalmente disonantes de ordenamientos, los cuales estructuraron y se vieron reforzados por diversas prácticas, tanto discursivas como materiales. Activistas de ambos lados estaban comprometidos en una lucha cosmopolítica con el fin de implementar sus ordenamientos, creando historias alternativas de ballenas, caza de ballenas en las Islas Feroe, el medio ambiente marino y la modernidad. El objetivo es entender lo que sucedió cuando estos ordenamientos se enfrentaron. En este artículo se argumenta que a lo largo del verano estos ordenamientos se alejaron, por consiguiente, ocultando de tal manera la diversidad de opiniones y el debate dentro de la sociedad en las Islas Feroe en torno al grindadráp. De tal modo, se suprimieron ordenamientos alternativos, A medida que fueron suprimidos tales ordenamientos, especialmente los expresados por activistas de las Islas Feroe que argumentaban que la práctica debía cesar debido a los altos niveles de toxinas en la carne de ballena piloto.
\end{abstract}

Palabras clave: Islas Feroe, caza de ballenas, ontología política, cosmopolítica

\title{
1. Introduction
}

The fairy folk were abroad in the Faroe Islands during summer 2014: strange beings, clad in fearsome black livery and speaking outlandish tongues appeared across the countryside. As with the huldufólk - hidden people - of legend, they were normally found uttangarðs, in the lands outside of the village, clustering around particular natural features. These modern elves were regularly encountered on the coast or at sea. They populated lookout points over the various bays where long-finned pilot whales (Globicephala melas) are driven for slaughter - a process known as grindadráp. At other times they would appear on small boats patrolling the fjords and sounds of the Faroese archipelago. These unusual beings were the most obvious manifestation of an environmental campaign, Operation Grindstop 2014, by the animal welfare group the Sea Shepherd Conservation Society (SSCS).

Grindstop 2014 was officially active over three months, from the beginning of July until early October. Over this time several hundred SSCS activists passed through the islands to a mixed reception from Faroese people. SSCS were one of the hottest topics in the Faroes all summer, with the Faroese media gleefully covering their every move and any action engendered much discussion. It was a tense time; clashes and arguments between SSCS and Faroese pro-whaling advocates and authorities were prominent throughout.

This article views the events of Grindstop 2014 as "political ontology" (Blaser 2009). This approach asserts that humans engage with the world through 'systems of ordering': in essence the infinite nature of reality can only be understood and acted upon through categorizations, which bring order. This is not simply a matter of systems of orderings being mapped onto an absolute, fixed, universal external as in social constructivist approaches. Instead, what occurs are 'cosmopolitical' struggles (Latour 2004) to enact a particular form of reality (see Nustad 2011: 89-90 for a review). Rather than "...one external reality forming the basis for a multitude of representations, practices are seen as constitutive of a multiplicity of realities" (Nustad 2011: 90) - multinaturalism rather than multiculturalism (Blaser 2009). These multiple realities are emergent products of the relation between objects, contingent upon practices of ordering (Kendall and Wickham 2001). In such an ontology representations form part of systems of ordering as 'stories' which may have material effects. Representations are thus considered objects interpellated with systems of ordering (Kendall and Wickham 2001: 161). Orderings can be understood to be "simultaneously semioticised and real" (Roepstorff and Bubandt 2003: 26). 
Social scientists are becoming increasingly interested in political struggles where actors assert particular combinations of partial and overlapping orderings and the consequences of 'ontological dissonance' (cf. Blaser 2009; Blok 2011; de la Cadena 2010; Escobar 1999; Mol 1999). Such dissonance has been identified at the heart of several environmental issues. For example, Blaser has described how efforts to allow an indigenous group to resume sustainable hunting in a National Park in Ecuador foundered because two groups, 'Spanish biologists' and the indigenous Yshiro, considered the form of reality differently, despite planning having taken a "participatory approach." This had concomitant implications for 'sustainable' hunting: within the Yshiro ontology, reality - yrmo - is constituted of relationships, primarily human-human but also human-animal. Within this ontology sustainability was understood to entail the appropriate maintenance of these relationships and the primary concern ensuring that the Yshiro were able to benefit from the resumption of hunting in an egalitarian manner. This led to hunting practices alarming to biologists, at odds to their understanding of sustainability. These scientists, in concert with other actors, sought to have the hunting suspended (Blaser 2009).

In turning to political ontology, Blaser highlights how enactments of forms of reality are integral to actors' behavior in and representations of the world. Creating a hunting regime involved implicit assumptions about what 'sustainability' entailed - assumptions that were not shared by the respective parties involved. This 'equivocacy' over what sustainability meant was revealed through action (cf, Viveiros de Castro 2004). A political element was then revealed in the ability of the scientists and their allies to end the hunting. Hunting sustainably is only permissible in this case if it is predicated on a particular ontology. Despite a participatory approach, it was not permissible for yrmo to threaten 'real' reality (Blaser 2009). Taking a political ontological approach allowed Blaser to avoid taking a definitive side in the conflict - rather than simply being 'wrong' or cynically manipulating indigenous rights discourses, Yshiro and scientists are revealed to be active in processes of translation between worlds, rather than representations. The 'hybrid' that emerges is deeply political as some groups' worlds may be enacted at the expense of others, a key interest of political ecologists (Escobar 1999). This is one of the advantages of taking a political ontological approach: the normative natures of particular ontologies are revealed and previously hidden politics can be glimpsed (cf. de la Cadena 2010; Law 2001).

In tales collected in the $19^{\text {th }}$ century, the huldufólk were thought to live in a parallel alternative version of the Faroe Islands, which overlapped with the world of the Faroese in certain places (Wylie 1987: 41-64). This article explores how SSCS and pro-whaling Faroese enact differing systems of ordering overlapping at times around the practice of grindadráp. It aims to gauge and understand the effects of this 'hybrid' ontology from a political ontological perspective. The article is structured as follows: following this introduction is a brief description of methods and empirical material from which this article is drawn. The two different orderings are then described, followed by discussion regarding the effects of the clash of orderings during Grindstop 2014.

\section{Summer of orderings (methods)}

Several forms of data went into this particular 'methods assemblage' (Law 2004). Over three months in the Faroe Islands, coinciding with Grindstop 2014, I conducted 18 semi-structured interviews with people to greater or lesser extent involved with grindadráp, either for or against it. Questioning focused on scientific practice around grindadráp, on-going changes to grindadráp's various institutions and the Grindstop 2014 campaign itself. Initially respondents were selected purposively and later through snowball sampling, following initial interviews (Bryman 2004: 333-335). Respondents included a senior member of the SSCS campaign; members of the board of the Pilot Whalers Association (Grindamannafelagið) (PWA); 'pilot whalers' (see below); scientists, police and bureaucrats involved in monitoring and governance of grindadráp; and several Faroese people who are publicly active against grindadráp. These interviews were recorded and transcribed verbatim unless circumstances prevented it. In addition, I spoke to numerous people during my time in the Faroes, including SSCS volunteers at viewing points. I also spent considerable time with the marine mammal scientists of the Faroese Natural History Museum (Náttúrugripasavnið), discussing and observing their activities. I also attended public events around Grindstop 2014 whenever the circumstances allowed. This information was supplemented by examining 101 documents, videos and websites. These included Faroese print and electronic media, ${ }^{2}$

\footnotetext{
2 Thanks to Bjarni Mikkelsen, Mirjam Joensen, Erika Hayfield and Anni Djurhuus for their assistance with translation and grammar.
} 
official Faroese government documents and also the media produced by SSCS. Videos and audio were transcribed prior to analysis.

During and following data collection, in dialogue with social scientific literature, certain patterns began to emerge in the data (Law 2001). Particular stories about pilot whales and whaling began to manifest at particular times and places, from particular people. What was notable was the dissonance between these stories. Through communicating with respondents it became increasingly possible to describe these appearances of systems of thinking and knowledge, or 'orderings', and the uses of these orderings as they appeared to me (cf. Kendall and Wickham 2001: 79). Through these systems of orderings a political ontology of Grindstop 2014 emerged.

\section{A brief introduction to grindadráp}

Marine mammals have been a part of Nordic people's diets for much of their histories; indeed the consumption of pilot whales in the Faroe Islands may pre-date or be coterminous with Nordic settlement around 800AD (Kerins 2010: 82). Practices of whaling changed throughout history, becoming increasingly organized and codified within the developing Faroese state. Today, grindadráp combines "...elements of traditional, community-based oversight and top-down, colonial exhibitions of power ... controls that are intended to keep the event as traditional, efficient, humane and sustainable as possible" (Fielding et al. 2015: 38). Statistics on pilot whale catches have been kept since 1584 and are unbroken from 1708 (Joensen 2009: 59). 'Pilot whaling regulations' (Kunngerð um Grind) were first adopted in 1832 and are updated and administered by the Faroese Ministry of Fisheries. To this day, the Faroe Islands are divided into six whaling districts, with a total of 23 bays classified as authorized for whaling (Joensen 2009). The Faroe Islands are founder members of the North Atlantic Marine Mammal Commission (NAMMCO), and cooperate with neighboring countries in collecting data on pilot whales, conducting sighting surveys of marine mammal populations in the North Atlantic, most recently in summer 2015. The most recent survey for which results are available was conducted in 2007 and produced a pilot whale population estimate of 128,093 (NAMMCO 2012: 241). NAMMCO has assessed grindadráp and declared that its impact on pilot whale populations is negligible (NAMMCO 1998: 97-8).

Grindadráp itself is a spectacle (Figure 1): a pod of pilot whales ${ }^{3}$ (sighted from shore or sea) is driven by a flotilla of boats into a designated whaling bay and beached. Groups of people onshore then secure and systematically slaughter the whales. In the process much blood is shed, turning the sea red. Grindadráp is spontaneous, dependent on the appearance of pilot whales at the right place and time. When pilot whales are sighted, a special official in the police force ${ }^{4}$, the sýslamaður (sheriff), will, in discussion with local grindaformenn (whaling foremen), decide whether and where a drive is to take place (Fielding et al. 2015). In making the decision they assess the prevalent weather conditions and the size of pod. Participation is ad hoc and voluntary - participants involve themselves as and when they wish in whatever tasks they feel they can contribute with. ${ }^{5}$ The whales are then hauled onto land and the meat is divided according to the systems of the local whaling bay, among participants and the local community (Joensen 2009). Pilot whale meat is one of a series of non-commercial subsistence activities practiced in the contemporary Faroe Islands; pilot whale meat is readily swapped for other produce within local food exchange networks. Collectively, these practices remain prevalent - the most recent census recorded that a large majority of households across the country accessed free food sources. ${ }^{6}$ Historical and social scientific accounts of the Faroe Islands have described the precariousness of living in the North Atlantic and the role grindadráp played in ensuring survival (Gaffin 1996; Wylie 1987; Wylie and Margolin 1981). Nowadays, whilst the threat of starvation no longer looms, writers continue to highlight the Faroe Island's precarious position as a minor part of the Kingdom of Denmark with an economy heavily

\footnotetext{
${ }^{3}$ The largest pod ever recorded was 1,200 pilot whales in 1940 (Bloch 2007: 54), the average number of whales in a beached pod is 140 (Bloch 2007: 9).

${ }^{4}$ Faroese police and defence are provided by Denmark, of which the Faroe Islands are an autonomous part. Police officers are largely ethnically Faroese (Fielding et al. 2015: 41). The role of sýslumaður is unique to the Faroe Islands.

${ }^{5}$ Owing to the opportunistic, community-based nature of the grindadráp it is difficult demarcate the limits of the practice, as meat is shared within various exchange networks and numerous different roles are performed. 'Whaler' is an inadequate English language word which conjures up an image of a professional who hunts whales out at sea, whereas no one involved in a grindadráp is paid money to participate, bar the sýslumaður who manages it. See Joensen (2009), Kerins (2010) and Fielding et al. (2015) for fuller descriptions of practice.

${ }^{6}$ Some 12,780 out of 17,441 Faroese households asserted they accessed "supplemental food" (fish, lamb, pilot whale, potatoes or other [e.g. birds or hares]) (Hagstova Føroya 2014).
} 
dependent on the fishing industry. Grindadráp can arguably be understood as one a series of economic and cultural practices that mitigate the uncertainties and precariousness of life in a land that has changed over the past 60 years and continues to change quickly (cf. Cannady 2014; Gaini 2011, 2013; Kerins 2010). Grindadráp is also distinctive as it has long been seen by both outsiders and Faroese as a distinctive and a particularly emblematic part of Faroese culture, recreating as it does "Faroese norms of collective enterprise" (Wylie and Margolin 1981: 102) and thus garnering national attention in comparison to other subsistence practices (Joensen 2009; Naurby 1996). The contemporary Faroe Islands is depicted as a modern Nordic country, where traditional practices retain a certain salience, and a tightlyknit feeling of belonging to a definite Faroese community remains (Gaini 2013).

The world at large became aware of grindadráp in the 1980s, with a number of environmental organizations beginning to protest against the practice since 1985 with sporadic campaigns occurring since (Joensen 2009). These campaigns have involved letter writing, occasional sabotage efforts and attempts to enact an economic boycott of Faroese (largely fish) products (Kerins 2010). Since the 1980s SSCS have been one of a group of organizations protesting against grindadráp. As such, SSCS have periodically campaigned in the Faroe Islands prior to Grindstop 2014, most recently in 2011, where their activities were broadcast as part of the television series Whale Wars. Partially as a reaction to the various protests, significant changes have occurred in governance of grindadráp: the PWA was formed, research was funded and continues into the population status of the pilot whale and a variety of changes to whaling equipment and methods were instituted in order to reduce the length of time required to kill a pod of pilot whales (Fielding 2010: 433). Support for grindadráp, whilst difficult to gauge precisely, remains high within the Faroese population: one random, weighted survey of 528 people (approximately 1\% of the population) conducted before SSCS arrived in the islands determined 77\% of those sampled felt that it was right to continue driving whales, with $12 \%$ stating it should cease (Gallup Føroyar 2014).

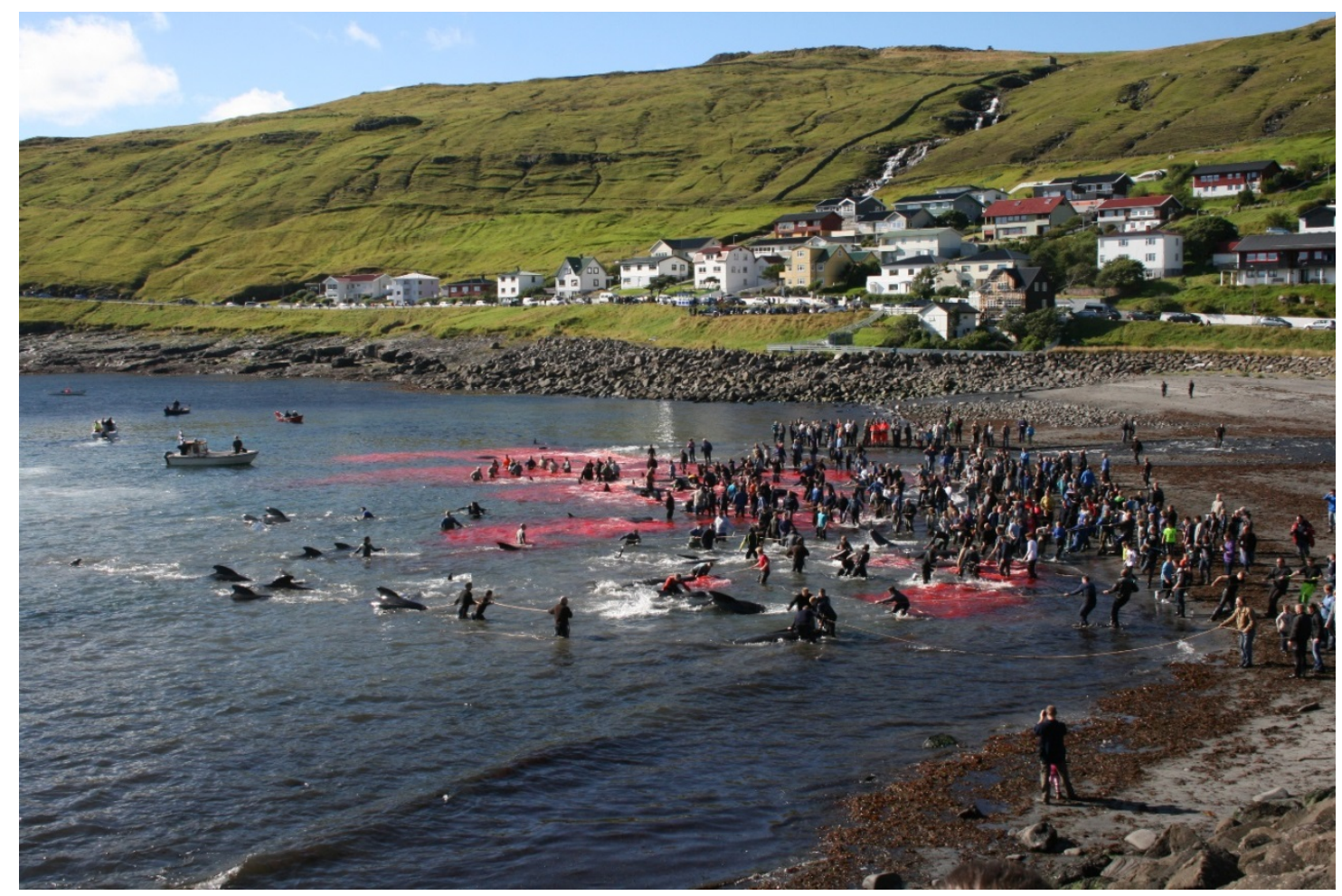

Figure 1: Grindadráp in Sandavágur in 2013. Source: Bjarni Mikkelsen.

\section{Summer of strife}

Grindstop 2014 was first announced in September 2013 (Sea Shepherd UK 2013). The campaign did not begin in earnest until the 17th of June at an opening press conference (SSCS 2014c; 2014d). The campaign then continued for the next three months, ending on the 2nd of October, having cost SSCS 
US\$458,212 (av Rana 2014). The campaign had two main thrusts: interfering with grindadráp itself and publicizing any that did occur; and hoping to draw international attention to the Faroese practice (SSCS 2014a). On several occasions, SSCS figures asserted they would return the following year with more volunteers (e.g. Kringvarp Føroya 2014) ${ }^{7}$.

Many SSCS members participated in Grindstop 2014: SSCS stated that some 500 volunteers were in the Faroes over the summer coming from 27 countries (SSCS 2014d; 2014i). The campaign consisted of several different elements. The first, the 'Onshore Crew', made up the greater number of SSCS members on the islands. The second element, the 'Offshore Crew', were a smaller group, more rigorously selected, who utilized smaller and larger boats. The number of actual SSCS fluctuated throughout the campaign, with 70 the typical number present at any one time according to a Faroese report (Klakstein 2014). The amount of time each volunteer stayed in the Faroes varied, but one SSCS respondent stated that the average was between 14 to 20 days. For the most, part volunteers paid their own fare to come to the Faroes and food costs whilst there, with SSCS paying for accommodation. The final element was a media campaign, which included videos, reportage and commentary, the latter notably often provided by SSCS founder, the controversial Paul Watson (Nagtzaam 2014). ${ }^{8}$

The various parts of Grindstop 2014 performed different functions over the summer. The onshore crew were the most prominent: each day they occupied various observation points around whaling beaches, usually in groups. They were extremely obvious in their black clothing bearing SSCS' distinctive logo (Figure 2), usually in full view of passing traffic. Their daily role was to watch for any pilot whale or dolphin activity ${ }^{9}$ or signs that a grindadráp was taking place and raise the alarm. They were also the most publically accessible part of the campaign for the majority of Faroese. The onshore crew acted during grindadráp. Only one whale drive actually took place during Grindstop 2014, at Sandi, where 33 pilot whales were killed. In attempting to disrupt the event six onshore volunteers accessed the beach; several volunteers entered the water and attempted to drive the whales away from the beach while others filmed events (SSCS 2014n). All were ordered by police to desist and subsequently arrested and found guilty of interfering with a whale drive (a crime under Faroese law); each volunteer was fined US\$153 and a deport request was sent to Denmark (Bertholdsen 2014a; SSCS 2014m; 2014n).

The Offshore Crew's role differed slightly: two larger boats would 'patrol' Faroese waters, while small fast boats were tasked with intervening in any grindadráp situation. Where possible, this involved driving pilot whales away from the islands. This occurred twice: at Haraldssund in July, in conditions deemed too rough for grindadráp, SSCS were able to herd a pod of 20 whales out to sea (SSCS 2014e; 2014h). Later, in September, one boat was seized and three crewmembers arrested following a public chase after SSCS volunteers attempted to drive away a school of several hundred white-sided dolphins. As a decision had been made already not to kill the animals, Faroese authorities requested SSCS desist from their activities and subsequently charged the volunteers with breaching the animal welfare rules (Bertholdsen 2014b). Prior to this, eight Offshore Crewmembers had been arrested and three boats seized at the grindadráp at Sandi (described above) (SSCS 2014k).

Finally, various online media were part of Grindstop 2014: these included videos, reports of events, 'investigations' (e.g. Vermeulen 2014b) and commentary by senior SSCS members. There were also public events documented online: the initial press conference, the arrival of celebrity supporters (most prominently Pamela Anderson) and a public debate. Several of these were streamed live, with recordings remaining accessible. One SSCS respondent stated that the media campaign was aimed in part at foreign tourists, with the hope they will boycott the Faroes if they are aware of grindadráp.

There were several notable reactions from Faroese people to the activities of Grindstop 2014; high levels of internet access and knowledge of English ensured that the Faroese were fully informed of SSCS' activities and were able to comment actively on social media. Likewise Faroese-language media regularly reported and commented on the campaign. Officially, the Faroese government's position asserted the right

\footnotetext{
${ }^{7}$ In 2015 SSCS conducted a similar, but larger, campaign Operation Sleppið Grindini.

${ }^{8}$ See Nagtzaam (2014) for a lengthy discussion of the legal controversies of both Paul Watson and SSCS, including the former's current life on the run, having skipped bail in Germany (661-663). Several respondents recalled the 1986 SSCS campaign in the Faroes: SSCS allegedly shot a line rifle at police (SSCS maintained they were returning fire) (Nagtzaam 2014: 635).

${ }^{9}$ The Faroese also drive white-sided dolphins and (less frequently) bottle-nosed and Risso's dolphins (Ministry of Fisheries 2014). It should be noted that it is illegal to hunt Risso's dolphins and in the event of this occurring the carcasses are confiscated. Bottlenose whales are sometimes killed and eaten when they strand, during the summer of 2014, 3 bottlenose whales stranded together and were killed.
} 
of people to oppose and protest against grindadráp within the bounds of Faroese law but stated they had "no basis for dialogue or cooperation with [SSCS]" (Wang 2014). SSCS activists were largely tolerated but were met with overwhelming force in the event of grindadráp: Danish military forces were stationed in the Faroes throughout the summer and large numbers of police deployed rapidly to relevant whaling beaches whenever a whale drive looked to be taking place (e.g. at an intended drive in Hvalba [Olsen 2014]) and quickly sealed off the area. During the summer, the official response was criticized for failing to actively contest SSCS' media campaign (Lindenskov 2014f) and the Faroese parliament discussed whether more action should be taken in future (Gregersen 2014).

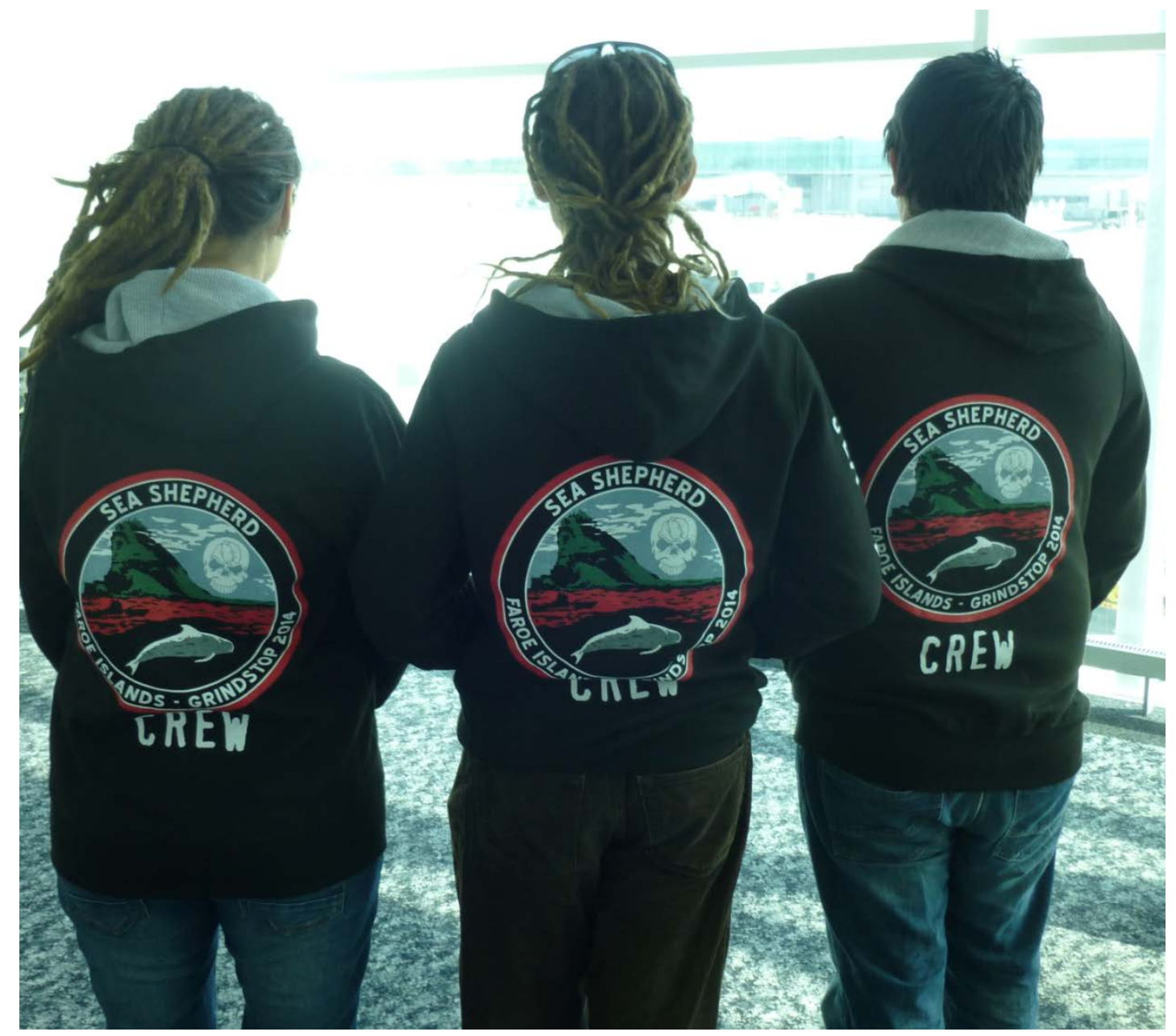

Figure 2: Three SSCS onshore crewmembers, displaying the Grindstop 2014 logo. Source: Author.

In sum, the summer of 2014 was largely quiet with two visible groups (SSCS and the Faroese authorities) awaiting the onset of grindadráp. When this occurred, both sides would speed to the drive, with the authorities arresting any SSCS that succeeded in getting close. Throughout Grindstop 2014 SSCS' media continued broadcasting, intensifying around events, with Faroese commenting on and contesting much of its output.

\section{A tale of two systems of orderings (analysis)}

Social scientific accounts of conflicts around whaling have repeatedly drawn attention to the dysfunctional nature of many of the interactions between different actors (e.g. Blok 2011, Epstein 2008, Kalland 2009). Such a situation was noted by respondents on both sides during Grindstop 2014, who saw little prospect of serious dialogue. For example, one senior member of SSCS stated: 
We can maybe come together and chat, but Sea Shepherd will never compromise ... we will never come to a stage where we said: "you can kill so many as long as you don't kill that pod or you can kill this pod." We don't compromise. Our bottom line is, don't kill these whales.... So we're not here for cultural exchange.

A board member of the PWA was similarly clear when interviewed:

... we apparently seem to be living in two different worlds. The urban culture trying ... to impose their point of view to the Faroe Islanders. ... [telling] us how we shall live in the Faroe Islands.

Despite this separation, it was also clear that actors were aware of what their opponents were doing and saying and reacted accordingly. In this analysis, Grindstop 2014 is seen as a political ontology, within which SSCS and Faroese pro-whaling (FPW) actors sought to enact their systems of orderings within a cosmopolitical struggle creating a hybrid (cf. Escobar 1999) continuously unfolding throughout the summer. Internal to the greater SSCS and FPW orderings ${ }^{10}$ are numerous discrete, partial and often supporting systems of orderings. Part of the political struggle thus entailed when and where particular orderings were articulated and acted on (cf. Kendall and Wickham 2001; Mol 1999) - indeed, SSCS and FPW actors occasionally drew upon the same systems of ordering. In attempting to enact their systems of ordering actors discursively represented themselves and their opponents (as seen in the quotes above). Following a political ontology approach, these representations are seen to have a recursive relationship with the different embodied experiences of grindadráp of those involved in the debate, connected to particular practices of engaging with the world. Within this ontology, pilot whales, the Faroese landscape, SSCS and the Faroese become ordered differently through a series of practices, which are simultaneously discursive and material.

In sum, during summer of 2014, two overlapping systems of orderings were prominent in the Faroe Islands, their dissonance becoming visible at particular points of 'equivocacy' (Viveiros de Castro 2004). These manifested particularly around the very nature of the pilot whale itself. Thus the titular global 'love-iathan' of SSCS became opposed by the 'meat-whale' of the FPW ordering. The following sections examine this and other manifestations of equivocacy between the two sides: around grindadráp, pilot whalers and SSCS.

\section{Ontologies of pilot whales}

Several orderings of pilot whales emerged during Grindstop 2014. SSCS actors prominently ordered pilot whales as sentient, individual rights-bearing beings. This was laid out by Paul Watson: "Taking the life of an intelligent, self-aware, wild, sentient being is murder and every fabricated justification the murderers or those who sympathize with murder post, does not change that fact" (Watson 2014a). Similarly, at the opening press conference, one SSCS spokesman replied to a journalist "we view the whales the same way we would view a human: that to kill a whale is murder. I have the same reaction if someone were to attempt to kill you: I would interfere" (SSCS 2014d). In this ordering, pilot whales' human-like attributes were stressed (Figure 3), with concomitant actions required when whales are killed. This is most obvious in the attempts to prevent 'murder' by intervening at grindadráp but also manifested in the sorrow SSCS members expressed at various times - for example in making gravestones for the bottlenose whales that stranded and were killed on Suðaroy (Poulsen 2014, see footnote 9, above).

Pilot whales are also ordered as rights-bearing by dint of certain features. The first feature is their intelligence, in one video the head of the Land Crew asserted "all sentient beings have the right to a life and to live free of being tortured" (SSCS 2014g). This intelligence is linked to their social behavior, which provides explanation for why individual animals do not try to escape grindadráp, they are interpreted as standing in solidarity with their families and selflessly trying to protect one another (SSCS 2014d). ${ }^{10}$ The FPW ordering sometimes felt like simply a Faroese ordering, however it is important to remain aware that not
all Faroese people view grindadráp in a positive light. 
Linked to this was a conception of the 'innocence' of pilot whales, particular vis-à-vis humanity. One volunteer explained her motivation for participating in Grindstop 2014 "I was really upset with how ruthless humans can be ... just killing something that innocent and that gentle" (SSCS 2014i). Indeed this innocence is one of the reasons why pilot whales need SSCS (see below). Pilot whales' beauty was also important, one of the crew who helped drive away the pod at Haruldssund (above) spoke of how the pod made for a beautiful sight, with partial reward for succeeding in moving the whales "a lot of pleasure just to see the [animals] themselves" (2014e).

Alongside these 'positive' reasons to protect pilot whales, SSCS would describe pilot whales as 'endangered' even if grindadráp is not depicted as the primary cause of this decline (see Workman 2014). In making such claims, scientific orderings of cetacean species were periodically drawn upon and uncertainties in estimating the number of pilot whales were stressed consistently by SSCS members in interviews and at public events. In doing this, reference was made to the International Union for Conservation of Nature (IUCN) Red List entry for the species, which classifies the long-finned pilot whale as "data deficient" (Taylor et al. 2008). ${ }^{11}$ Elsewhere, SSCS have accused the Faroese government of "lying when it claims abundance or sustainability in the drive hunt" (Vermeulen 2014c). Furthermore, grindadráp, involving as it does the killing of a whole pod of pilot whales, is particularly bad due to its indiscriminate nature. Not only does this inflict additional suffering as pilot whales die with their relatives, but it also wipes out a whole genetic group (Workman 2014). Within this ontology, pilot whales (and the oceans they are metonymic for [cf. Kalland 1993]) are faced with multiple threats such as pollution and overfishing. As one respondent put it:

I would say our oceans are dying. If you look at just what is happening ... if you look at the predictions that some of the best scientists are making, is that [by] 2048, our oceans are going to be dead. These people are taking whole pods of animals in an ecosystem out of an ecosystem.

Pilot whales are enmeshed in complicated ecological relationships such that if the pilot whale goes extinct the ocean itself will be irrevocably damaged. A globalized ontology, the world is a network of interdependency, if pilot whales die, the ocean continues to die and subsequently humanity also dies. Furthermore, as a member of the Land Team argued, pilot whales do not abide my national boundaries, contesting the Faroese right to utilize a common good. This was echoed in internet commentary: "Cetaceans belong to the oceans, not to humans of any nationality" (West 2014).

Tied to this ecological need to preserve pilot whale life is a symbolic need: whales are symbols for the wider environmental movement and as such should be protected. As ocean going creatures whales do not 'belong' to the Faroese, but are instead thus conceived of as property of the sea, which needs protection. As one senior SSCS figure stated publicly

...if we cannot save the whales then I don't see how we gonna save tunas or the species that people just don't give a damn about ... and in the end this is about saving the oceans... Marine life is many workers on this earth, on the oceans and the ocean is that machinery that keeps this planet alive" (Workman 2014).

Within this ordering, humans are just one of world of interlinked, equal species, and the claims that animals can be harvested sustainably is simply foolish arrogance, a mistake that has been made before. As an SSCS respondent stated:

\footnotetext{
${ }^{11}$ During Grindstop 2014, to my knowledge, no one from SSCS mentioned that the IUCN listing also states "[t]he harvesting of [pilot whales] for food in the Faroes and Greenland is probably sustainable" nor that many of the sources cited by IUCN are the same as those used by the Faroese authorities (Taylor et al. 2008).
} 
All we're saying is that big statistical studies has proven we don't have enough data. ... So all of these statistical models, that people base their predictions on, they're just statistical models, and it is only as good as the data you feed it. So if you don't feed it accurate data, it's going to give you bullshit answer. And if you don't keep in mind things like by-catch, which is in an enormous risk to these pilot whales, by-catch, natural death, death because of pollution, death by big ships in their migration lanes, things like that. So how can you claim that's accurate statistics?

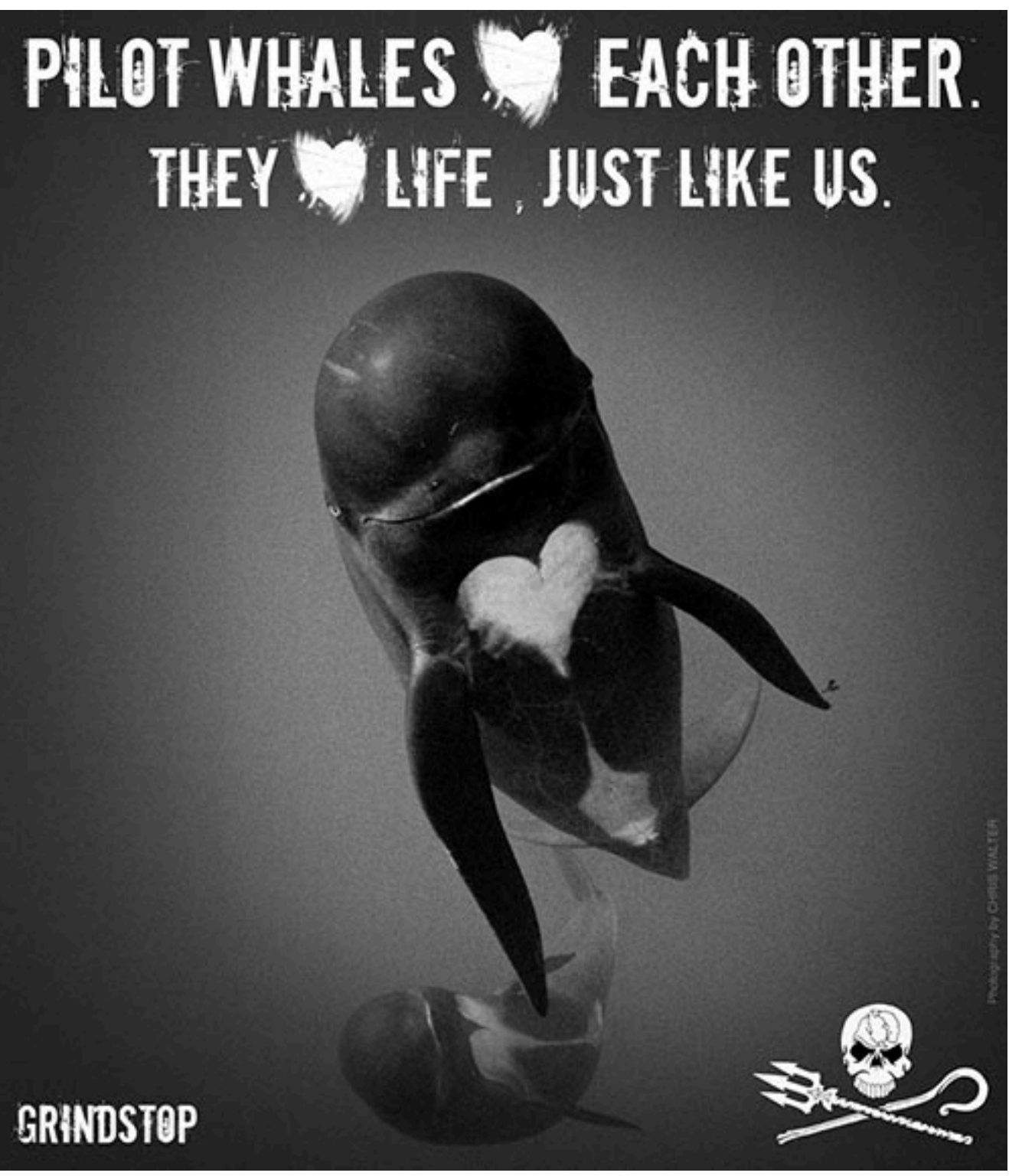

Figure 3: A SSCS promotional image. Pilot whales are ascribed positive, human-like features within the SSCS ordering.

Source: http://www.seashepherd.org/grindstop/images/pages/about-campaign-pilot-whaleslove-each-other-01-500x573.jpg

By contrast, pilot whales FPW actors ordered pilot whales quite differently. In this ordering, pilot whales are not considered special compared to other food animals. Respondents were aware that the animals suffered during whale drives but felt that reasonable and continued efforts were made to reduce this as much as possible; one whaler stated "[y]ou have to respect the animals as well." Indeed, commonly a comparison was made with industrial farming practices elsewhere, for example a Faroese 
MP to the Danish parliament responded to criticism by asserting that slaughtered free living whales had better lives than industrially-farmed pigs (Lindenskov 2014c). By comparison another whaler felt grindadráp was clean and efficient:

Because the spinal lance has proven to be [a] very effective method of killing the whale, ... as a method of killing an animal, it's very, very efficient, along with the blunt hook, of course. You drag the whale in its nostrils of course, I don't know if the whale feels pain or not. I suppose it does. As would we, if we were dragged by our nostrils, of course. ... I think it's so effective that it's a very good thing.

Thus there is a clear similarity but also difference between the two orderings: Faroese whalers are aware that pilot whales are more than inanimate objects, however this does not mean pilot whales' lives should not be forfeit before human need.

Within FPW orderings, the pilot whale is not threatened by grindadráp; appropriate systems prevent overexploitation. What is incontrovertible is that the oceans are polluted and poisons are collecting in pilot whale meat. The cause of this pollution is considered to be elsewhere, in larger, more industrial nations such as the UK. This view of nature occasionally manifested itself in reactions to antiwhalers: one man at a public debate castigated SSCS' representatives yelling "It is you who polluted the fish, it is you who polluted the whales and now you come here and impose your lifestyle upon us!" (Workman 2014). In pro-whaling rhetoric, the environmental impacts of the Faroese (including grindadráp) are often framed as insignificant globally, well within nature's ability to recover. The pilot whale that emerges is thus decidedly local: it is a Faroese resource that can be harvested sustainably provided appropriate monitoring is in place. Furthermore, it is the global that is poisoning pilot whale meat - those who wish to fix things should look elsewhere.

The argument for sustainability of grindadráp is built on several bodies of evidence: firstly, catch records (see above) suggest that overhunting is not occurring (Heinesen 2014). Secondly, the Faroese government funds scientific research (notably sighting surveys and sampling every drive), which has allowed for estimates of the overall pilot whale population and its reproduction rate in order to gauge the impact of grindadráp. This allows whaling advocates to assert that the percentage of the population taken (0.1\% according to one account [Bloch 2007: 56]) does not endanger the pilot whale population. These numbers have apparently been accepted internationally in various fora (e.g. NAMMCO 1998). Within FPW orderings, grindadráp is endorsed by science and has appropriate management systems in place, information about which is online (Lögmansskrivstovan 2014). The Faroese Ministry of Fisheries promotes grindadráp to a certain extent, e.g. recently subsidising new 'spinal lances' (mønustingarar) for each whaling district. Respondents involved in monitoring systems argued that whilst overexploitation was unlikely due to the opportunistic and non-commercial nature of drives authorities would become aware of and act upon any drastic decline in pilot whale numbers. Whilst this has never been put to the test, one respondent cited the bans on puffin hunting following noted declines in their reproduction as an example of how scientific knowledge is acted upon.

It is important to note that these orderings manifested at different times. SSCS orderings around the positive traits of the pilot whale, 'love-iathan', appeared most prominent when various members explained their motivation for being involved. Similarly, 'the meat-whale' was fundamental to FPW's orderings. Both sides drew on scientific orderings of pilot whaling. However, with the bulk of research on North Atlantic pilot whale populations part-funded by the Faroese government and suggesting that grindadráp is not threatening the species' survival it is far more prominent within FPW orderings. SSCS actors preferred to highlight uncertainties in data and in the possibility of managing complex ecological systems.

The bulk of the information presented above is in the form of representations; however these orderings are also influenced by actors' engagements with land and seascapes. FPW orderings are firmly rooted in a series of practices embedded in the landscape. The pilot whale that is enacted within FPW orderings comes to be known, in part, through the killing of animals - the sights, smells and sounds of killing, butchering and eating the meat-whale are unique to the Faroes nowadays. This is supplemented by scientific knowledge of pilot whales, where they are understood as populations rather than individuals. By contrast, it's harder to gauge the ways a diverse group such as SSCS come to know whales. Some, who have participated in other campaigns, will have encountered whales in other settings. Others will have 
perhaps encountered whales through whale-watching or in some other activity. Still others may have never personally encountered marine mammals directly, learning of them through a variety of media. The following sections explore how these different orderings of pilot whales lead to markedly different orderings of the practice of grindadráp, pilot whalers and of SSCS itself.

\section{Ontologies of whalers and whaling}

If killing pilot whales is considered murder, it follows that those responsible are murderers and practitioners of grindadráp akin to serial killers. Furthermore, the social nature and intelligence of the animals makes the possibility of humanely killing pilot whales impossible; within the SSCS ordering, grindadráp is always cruel. This cruelty is further exacerbated by a lack of necessity in SSCS activists' eyes. Occasionally, SSCS commentators would acknowledge the importance of grindadráp to the historical survival of the Faroese people. At other times, traditional aspects of the hunt were denied or downplayed; attention was drawn to apparently commercial aspects of grindadráp ${ }^{12}$ and Faroese links to other whaling nations such as Norway, Iceland and Japan. At such times, SSCS seek to frame all whaling as alike - illegal and a part of a corrupt global axis of evil, motivated solely by profit (e.g. SSCS 2014b, 2014j' Vermeulen 2014a, 2014b). Grindadráp is thus described as a shameful secret, blighting the otherwise beautiful Faroe Islands and also Denmark, who supports and represents the Faroes in various fora. In judging the (in)authenticity and necessity of grindadráp SSCS are following a common theme in anti-whaling campaigns (Barsh 2001; Kalland 2009). As a 'modern society' the Faroese are able to buy food from the supermarket and have no need to kill marine mammals (Watson 2014); claims of necessity were considered laughable, as one respondent put it:

We met a Faroese person, a women, and she said: 'I'm very poor, my car is ten years old.' That's how she measures poor. Now, for me, coming from a country that you actually see poverty, and people need something to survive, to actually have something to eat, otherwise they die, it's an insult when these people are saying: 'we need this to feed the population.

Grindadráp is thus said to be 'barbaric' practice akin to other vilified activities past and present, all the more shocking for its continuation in 'civilized' Europe. During Grindstop 2014, one SSCS respondent compared grindadráp to apartheid, once again highlighting the equivalence of human and animal rights, while another volunteer saw SSCS as fighting a moral crusade similar to Martin Luther King's civil rights movement. The barbarity of grindadráp is demonstrated by its public nature, with reference made to its visibility to the whole community including children. This barbarity is also seen as a hindrance to the Faroe Island's independent development: the Faroese are able to maintain grindadráp by being a "subsidy leech on Denmark's pelt" rather than developing whale-watching based tourism (Vermeulen 2014d). In this ordering grindadráp is preventing Faroese society joining the modern world.

The "brutal and needless" (SSCS 2014c) nature of grindadráp has necessary implications for those who participate. Pilot whalers were at best depicted as clinging stubbornly onto a tradition (Klakstein 2014) or as sadistic, psychopathic killers, who kill without remorse or regret. Watson stated: "We see any attempt to justify this slaughter as equivalent to someone attempting to justify rape, serial killing and child molestation" (2014a). As evidence for this, SSCS spokespeople would regularly draw attention to the apparent joy expressed by whalers, after the drive in Sandi one SSCS volunteer arrested stated:

I saw how people changed ... they were screaming, they were yelling, they made a party. It was like a big festival, they drank beer, they danced ... for me it felt like a big party and this is unacceptable (Workman 2014).

Faroese whalers thus not only drive whales for fun but are also disrespectful to the whales they do take. SSCS media asserted that meat is wasted and whales are taken gratuitously (SSCS 2014f, 2014l), one respondent stated, "[w]e've come across pilot whales being discarded, just lying there rotting" and

\footnotetext{
12 Small shares of pilot whale do find their way into shops and markets, likewise at least one restaurant in Tórshavn offers pilot whale steaks. This meat may have been sold to offset costs incurred during drives or be sold by private individuals (Joensen 2009 185; Kerins 2010: 136). I only ever found dried pilot whale meat on sale in the largest supermarket in Tórshavn.
} 
stated pilot whale meat is simply considered free dog food. This same respondent suggested that the Faroese should feel indebted to the pilot whale: "[w]hy don't they have a relationship of gratitude towards these animals now, trying to preserve them? Just because, the pilot whales were preserving them." In this ordering, whalers are also incompetent "amateurish killers" (Watson 2014a); stupid to eat food which contains so many toxins (see below). Indeed those feeding their children pilot whale meat were described as committing child abuse (SSCS 2014b; Watson 2014a). Finally, an SSCS respondent suggested that pilot whalers intimidate and threaten those who are against the practice (cf. Klakstein 2014).

Within the FPW ordering, driving pilot whales is considered both lawful and sustainable, as one Faroese MP put it (Gregersen 2014). One respondent at the Faroese Ministry of Fisheries asserted that grindadráp is legal as the moratorium of whaling only applies to larger cetaceans and, furthermore, the principles of the Rio Declaration on Environment and Development support Faroese rights to utilize their local resources. In contrast to SSCS arguments about 'Danish whaling', within FPW orderings grindadráp is considered to be a purely Faroese matter, whose rights are supported by the Danish state. ${ }^{13}$ Proponents of grindadráp frame themselves and their activities as rational and open; one interviewee argued that it was important that practices were visible to all and sundry, highlighting how there was nothing to hide. Within this ontology, people (both Faroese and foreign) are entitled to different opinions on the grindadráp, but 'the facts' should be made clear. As one whaler put it:

I can say that the majority inside whaling, or with the whaling Faroese people, it's polite. Even you have your opinion of not killing a whale, you are more than welcome to have that opinion, but please let me have my own.

As a consequence, Faroese pro-whalers (for example the PWA) during Grindstop 2014 were visible contesting SSCS' representations of grindadráp, tending to contrast their rational 'facts' with SSCS' 'emotional' arguments, which attack all whaling everywhere as the same (cf. Kalland 1993).

This perspective on science and rationality comes within a particular ontology of the past, present and future of the Faroe Islands. Within this perspective, as one interviewee articulated, the Faroes are understood to be a society in transition; 'tradition' and 'modernity' juxtaposed within people's lives. Grindadráp is just one of several subsistence activities (such as seabird hunting and sheep farming) practiced by different sections of the Faroese community in complement to 'modern' work and lifestyles. Within this perspective, there was no contradiction between enjoying nature and hunting animals for food and this was felt to be natural for many northern communities. In this conception, rather than a barbaric anachronism, practices like grindadráp allow the Faroese to mitigate the consequences of globalized modernity; notably maintaining a connection to their landscape and processes of food production, something that has been said to be lost in some other modern societies (cf. Bulliet 2005). As one respondent put it: "when you import meat, then you do not see the blood here on the seashore ... but when you eat meat, then an animal has to be or had to be killed in other countries instead of in the Faroe Islands." With the possibility for exchange with other foods, whale meat is thus a social good, but is also part of people's subsistence.

Faroese pro-whalers thus reacted angrily to the suggestion that food was wasted or that they killed whales for pleasure and whilst there are clearly cultural elements to grindadráp, these cannot be separated from subsistence. Indeed, it was reported in the Faroese press that pilot whale meat represents $25 \%$ of domestic meat production (Wang 2014), and during a public debate with SSCS, a single mother highlighted the importance of free food to her household (Workman 2014). In the FPW ordering, participation in grindadráp is the right of all inhabitants of the Faroe Islands; a historical and present part of individual and community subsistence (Heinesen 2014) and in the absence of convincing arguments against the practice in terms of conservation and cruelty (see below), pilot whalers persist. As one respondent put it:

\footnotetext{
${ }^{13}$ In November 2015, I attended a hearing of the Faroese committee of the Danish Parliament. Alongside several Faroese speakers, Sea Shepherd Global's CEO made a presentation. He argued that Denmark is party to various international agreements to protect cetaceans and in allowing and protecting grindadráp Denmark is in breach of these agreements. The sitting Danish MPs asserted that this was fundamental misunderstanding of the division of power within the Kingdom of Denmark: the Faroese remain outside of the EU and grindadráp is a purely Faroese matter.
} 
Why would you not maintain the knowledge and skill and experience necessary to use a food that comes to you for free? Why would you not continue to want to do that, rather than importing equivalent amounts of protein from somewhere else, at a great cost?

Within FPW orderings, subsistence and culture are irrevocably tied to notions of self-sufficiency, both on an individual and a national level. Pro-whaling Faroese usually articulated a position that it is better to utilize local 'Faroese' resources over imported substitutes. Within this ontology the Faroes are vulnerable, dependent on external sources for much food and lifestyle goods (Heinesen 2014). In this context maintaining traditional resource gathering activities reduces this dependence on the outside as well as providing a buffer against any disasters that occur. One whaler put it starkly: "Look around you, there's only sea ... [w]hy should we not eat whale meat? It's [the only] natural food resource that we have. So for me, it's more like a principle". Another stated: "I'd rather eat whale meat that has come from .... the beach in Tórshavn, than having to import beef from Brazil." Grindadráp thus symbolizes self-sufficiency on many levels: the rights of individuals and communities to support themselves and each other; the right for the Faroese to define what is necessary within their own society and as part of political and economic Faroese independence projects, within which food security is a part. There is occasionally another concern: if the Faroese bow to pressure and stop driving whales, what other food could then be circumscribed? Thus a concern for principle is also sometimes extant within FPW orderings. Practicing grindadráp can thus be considered to be part of efforts to enact a self-sufficient Faroe Islands.

Whaling is thus ordered quite differently to SSCS. The motivation for Grindadráp is primarily a desire to collect food, but it need not be unchanging. Indeed, one whaler I met stated he felt shame when he saw early videos of grindadráp. Since the 1980s there have been considerable changes to both the administration and practice of grindadráp, as noted earlier, research has been funded and efforts have been made to improve practice to make it more efficient and more humane (cf. Fielding et al. 2015). This included the development of the spinal lance, and mapping whaling beaches to improve driving, and is continuing with the development of a certification scheme for those who do the killing. Respondents stated that these changes were in part a reaction to criticism from abroad but also represented trends ongoing in Faroese society. One suggested that changes were "a natural consequence of the modern society ... you canalize, you arrange it more effectively." Respondents stated that, as a consequence of the changes, whales are killed faster and the meat was of a higher quality - one stated it was now like an animal being killed at an abattoir. Likewise, two respondents stated that driving the whales is better if the whales are not pushed too fast and unduly alarmed (until they're to be beached). Indeed, Faroese animal welfare legislation states that animals should be killed as quickly as possible (Lögmansskrivstovan 2014). Whilst it was acknowledged there were exceptions, and that mistakes do occur, whalers interviewed characterized themselves as motivated to kill the whales as swiftly and cleanly as possible, with a certain amount of self-policing extant. One respondent acknowledged that grindadráp is exciting but all prowhaling advocates denied that killing took place for fun. Each individual grindadráp is under the control of officials from the relevant whaling district (see above); all of whom were described as having an interest that each drive is an uncontroversial event.

\section{Ontologies of Sea Shepherd}

With grindadráp understood as an evil act perpetrated by ignorant and short-sighted men, threatening the whole planet, and ignored by the world at large, what is required is an adventurous, brave team prepared to take action and brook no compromise - people who can empathize with pilot whales SSCS' "clients" (SSCS 2014j). Within the SSCS ordering each whale kill is murder, which requires a direct intervention to prevent it. Failing that, what is required is for the world to wake up to what is going on in the Faroe Islands. This fits very much with the self-image of many SSCS members, both within Grindstop 2014 (SSCS 2014i) and elsewhere (Stuart et al. 2013). SSCS is built around the idea that previous successes in conservation could not have been achieved with dialogue; as Paul Watson, interviewed on Faroese television stated "You know, between 2000 and 2011 we were not in the Faroe Islands, which gave an enormous amount of time for other groups, which in fact other groups did go to the Faroe Islands to try and use dialogue. They got nowhere" (Kringvarp Føroya 2014). This 'crisis ontology' requires an uncompromising organization like SSCS willing to take immediate action, which itself serves to create highly charged situations; it placed numerous SSCS volunteers in a confrontational position. This was most obvious at the Sandi grindadráp, where the experience of whales dying and 
volunteers being arrested was visibly upsetting to the SSCS activists describing it (SSCS 2014n). It also occurred at other times, with the onshore crew's daily vigil, usually by roadsides, rendering volunteers an obvious target for abuse and mockery. By demonstrating their passion for whales and the ocean SSCS members hope to change people's views abroad and in the Faroes and through their actions they seek to create the circumstances for shifting people into their orderings. The SSCS orderings of grindadráp, whalers and their own identities opened up a path for action that contributed to the construction of a series of fraught, confrontational events that reinforced and reconfirmed SSCS actors' constructions of the situation. Love-iathan requires protectors.

Within the FPW ordering SSCS's 'emotional' views were typically interpreted in a negative light; the campaign being described as "imperialistic" by one respondent and the work of a "foreign enemy" by another. Grindstop 2014 was interpreted as an attempt to force the Faroese to end grindadráp, which drew critical reactions from many Faroese, who resented such coercion. Furthermore, SSCS were often felt to be cynically picking on a small, vulnerable community and failing to act against larger, industrial nations where it would make more of a difference. Respondents also described SSCS as dishonest; knowingly misrepresenting grindadráp. The reason for this was often felt to be to elicit more donations to maintain their organization and the lifestyles of SSCS' leadership. The confrontations SSCS' strategies engender were seen as a part of fundraising efforts (Lindenskov 2014b, 2014f, 2014h). SSCS was perceived as an organization under the iron rule of its founder, Paul Watson - who was described as a 'psychopath' (Vágadal 2014). With this, the unwillingness of other SSCS members to apologize or correct inaccuracies within Watson's writings was viewed in a poor light (Workman 2014). SSCS were viewed as disrespectful of Faroese public opinion, unwilling to engage in discussion and were seen to be actively shutting down those attempting to air pro-whaling views on SSCS social media (Workman 2014).

The SSCS volunteers were viewed ambivalently in the FPW ordering: their dedication impressed, but they were generally thought of as naïve city-dwellers (Gregersen 2014; Heinesen 2014), largely ignorant of grindadráp and the Faroes, having been led astray by SSCS. One respondent characterized the members of the onshore crew-team as single-minded and stupid. SSCS volunteers I met stated that often contact with Faroese was good-natured but they were regular targets for mockery. As an example, near to the position of these same volunteers sat a dummy 'SSCS volunteer' (Figure 4); whose 'equipment' (a beer bottle and toilet paper) referenced items SSCS members were accused of stealing. Volunteers also elicited feelings of sympathy on occasion: one respondent commented "they must be depressed" as we passed a lone SSCS volunteer slumped in a car looking out into thick fog. SSCS were also sometimes framed as ineffective - their limited numbers giving them little hope of stopping a drive once it reached land or reducing the Faroese's average pilot whale takes (Heinesen 2014). However, volunteers were also occasionally seen as dangerous; early statements about intending to intervene during a whale drive represented a direct threat to break the law and there were worries about how far SSCS would go. One politician claimed that his grandmother was frightened by SSCS' presence (Samró 2014). Likewise, SSCS' admitted record of using undercover volunteers (West 2014), added a level of suspicion to many dealings with foreigners or indeed anyone wearing black (Lindenskov 2014d). Discussions in the Faroese parliament about taking measures to ban SSCS also indicate that SSCS' presence was considered undesirable (Gregersen 2014). ${ }^{14}$

Within FPW orderings SSCS are understood to be attempting to impose their views on the Faroese and whilst opposing the grindadráp is acceptable - "everyone has the right to protest in the Faroes" stated one sheriff interviewed - breaking the law (interfering with a drive) is not. As such, a strong response from the authorities was warranted and enacted whenever a protest became illegal, with SSCS volunteers arrested and equipment seized on several occasions. Thus an event normally of interest to the local communities involved became of national interest as Faroese (and Danish) forces moved to protect the enactment of the food whale.

\section{Discussion - the effects of orderings}

This article has explored the political ontology of Grindstop 2014. The advantage of this approach is the analyst avoids taking an implicit, normative position of the form of reality of a conflict. There is a tendency within research on whaling for researchers to in effect 'take a side' - for example anti-whalers

\footnotetext{
${ }^{14}$ In 2015, the so-called Sea Shepherd Law was passed, which (amongst other things) provided for harsher sentences for those interfering with grindadráp. As of the time of writing it is being challenged within the Faroese legal system on the legality of other parts of the law.
} 
may be depicted as 'emotional', 'imperialistic' and 'irrational', primarily interested in raising money, rather than doing 'real' conservation work (e.g. Kalland 2009). This may be true, but it requires an independent definition about what conservation is, implicitly casting judgement on correct ways to 'be' in the world (cf. de la Cadena 2010). For example, to label SSCS 'irrational' without qualification is to deny that there are inherent uncertainties in estimating pilot whale numbers. It would also provide an incomplete understanding of actions: for example it is clear that creating events to be shown around the world was an aspect of many SSCS actions during Grindstop 2014. However, this is unlikely to be the only explanation; in my estimation, many SSCS volunteers did feel for whales in ways very different to FPW advocates and this was part of acting on and thus changing the world. For them, mourning whales was not just a gimmick. Thus, rather than one epistemology being 'correct', utilizing a political ontology approach shows that during 2014 both sides attempted to assert particular orderings of reality with different standards of evidence, interests and values. For SSCS, Grindstop 2014 is part of an attempt to enact a different global vision of humanity's relationship to the ocean and the animals within it; a battle against "ecological imperialism" (Watson 2014b). By contrast, within the FPW ordering Grindstop 2014 was "ethnocentric cultural imperialism" (Heinesen 2014); an attempt to undermine individual and national rights to harvest local resources. Grindadráp was thus variously seen as a barbaric hindrance to acquiring modern values and conversely as a part of a particularly Faroese modernity. In some ways, both orderings were similar: as 'Euro-American' assemblages they attempt to enact "a reality that is independent, prior and singular and definite", they just differed over what reality definitely was (Law 2001: 131).

At public events these orderings clashed; as one PWA board member stated: "we have two parts that stand in front of each other, and it's very hard to change their points of view, for different reasons". Outside of public clashes, greater agonism was sometimes present: people from both sides would occasionally talk about having changed an opponent's opinion and sometimes friendships developed 'across the divide'. At other times, there was more conflict and aggression towards one another (e.g. Lindenskov 2014a). For the most part the two sides did not come together as their actions maintained a distance between the two orderings, as well as engendering different embodied knowledge (cf. Ingold 2003) of on-going events. One pair of SSCS volunteers I met serve to illustrate this: two young Spanish women had both spent approximately two weeks at various lookout points around the Faroe Islands. When I met them they were several minutes' drive outside of Tórshavn. Isolated within their car, they'd had little contact with Faroese people. Lacking Faroese they had no access to local media and discussion. Indeed, they stated that even when SSCS volunteers did meet and discuss the campaign with Faroese people difficulties using English could be a problem for some volunteers. Furthermore, as I found on several occasions, at times SSCS volunteers were unwilling to speak freely without permission from more senior figures, something pro-whalers had also noticed. As such, due to their locations and by the practicalities of communication, it was difficult for SSCS volunteers to come together with the wider Faroese community.

In enacting their respective orderings, both sides demarcated their orderings by reifying the 'SSCS ordering' and the 'FPW ordering' - despite periodic efforts by SSCS to distinguish between 'Faroese' and 'Faroese whalers'. Separating participants in grindadráp from other members of society is difficult (see above) - pro- and anti-whalers may be friends, relatives and colleagues (cf. Gaini 2013: 35). As such, amongst respondents and in the media, there was general tendency to equate 'the Faroese' and 'the Faroese pro-whaling' positions. As the summer went on there was a feeling of entrenchment to the two orderings. There was a strong sense that 'the Faroese' should not be seen to be bowing to external pressure (Heinesen 2014). This was all reminiscent of other whaling conflicts where different actors seemingly move further apart from a shared understanding of the problem and indeed the world at large (Blok 2008, Blok 2011, Kalland 2009).

There are strategic elements to this "antagonistic cosmopolitics" (Blok 2011: 75): SSCS frame themselves as global warriors protecting their 'client', love-iathan, from an evil opponent. In vision, action and membership SSCS are international in scope. Their actions seek to win a conflict but are also contribute to the enactment of that conflict. With an identity and support based on an unwillingness to compromise, it is difficult for them to participate in dialogue over the nature of pilot whales. Throughout the media of Grindstop 2014 are opportunities for would-be supporters to join SSCS or to send support, financial or otherwise. Indeed one SSCS respondent explained "Sea Shepherd is not an organization anymore, it's a movement." SSCS actors thus order themselves and their activities as part of constructing a new world. In such circumstances, the views of Faroese pro-whalers are largely irrelevant to SSCS' 
global goals and dialogue largely pointless. Indeed, most media appeared to be aimed more at an international rather Faroese audience. By contrast, the representations and actions of defenders of the FPW were decidedly more local. FPW orderers would painstakingly explain this for both domestic and international audiences while the actions of Faroese (and Danish) authorities decisively enacted this ordering when SSCS activists crossed the line of 'legitimate protest.'

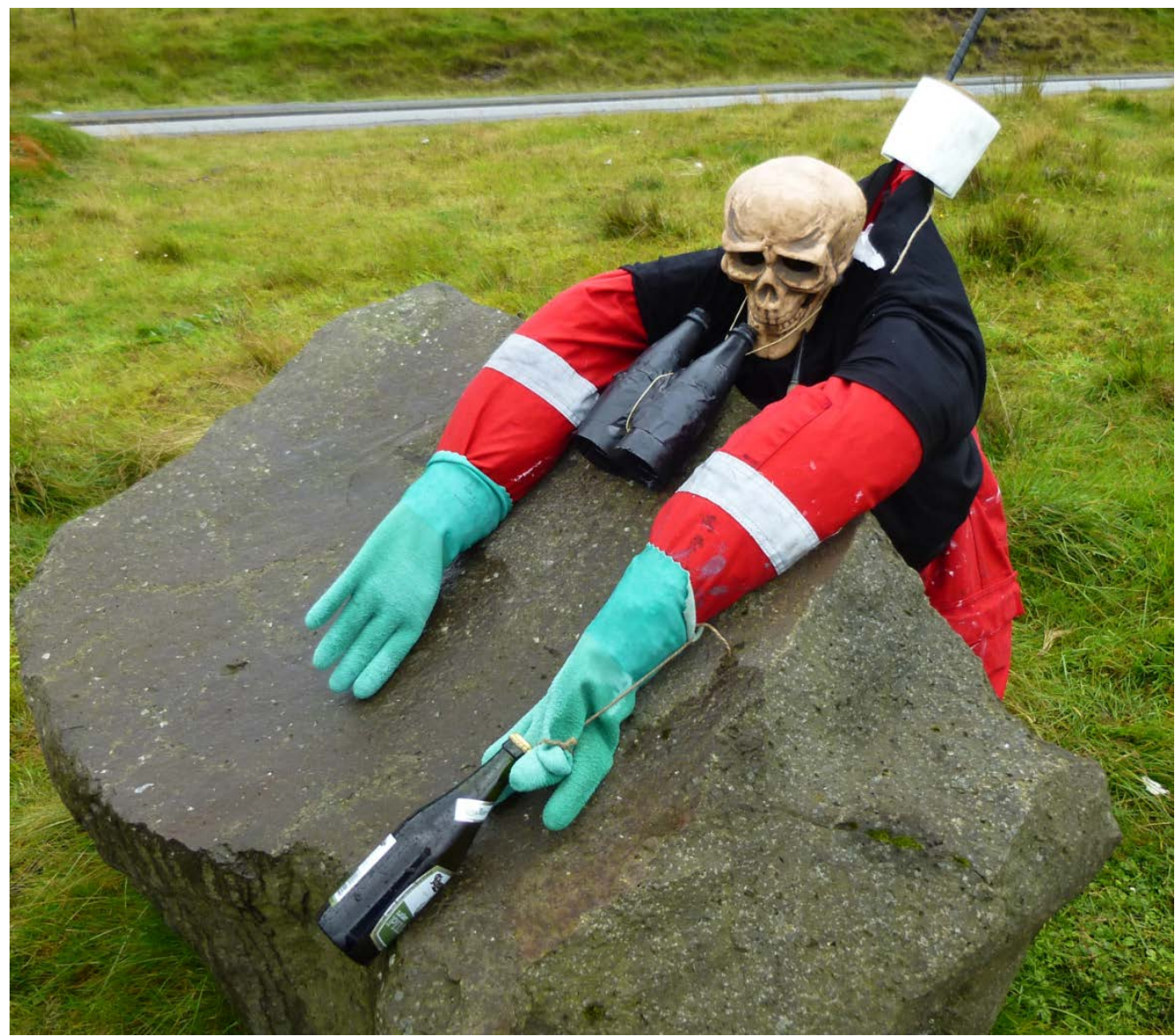

Figure 4: The SSCS 'crewmember' that appeared on the road into Tórshavn. Source: Author.

The long-term effects of Grindstop 2014 are unclear, however in the short-term it was common for people to suggest that it was actually contributing to support for grindadráp. By essentializing grindadráp as a distinctive and important part of Faroese culture (cf. van Ginkel 2004) both SSCS and FPW orderings contribute to making the debate about 'being Faroese' (and supporting grindadráp) or not. The dominant position the FPW ordering has regarding to science and continued efforts to improve killing methods prevent the conflict becoming about the nature of the pilot whale (i.e. is it actually love-iathan rather than the meat-whale?). Thus the hybrid political ontology that was enacted obscured the complexities of positions regarding grindadráp and Grindstop 2014. Several respondents and Faroese media suggested that SSCS were encouraging people to support the whale drives (e.g. Heinesen 2014); huge crowds of people tried to participate when a grindadráp was attempted at Hvalba, which respondents said was unusual and due to SSCS. One Faroese anti-whaling activist stated that her organization, Earthrace Conservation, was keeping a low profile

...because we also realize that, especially when [SSCS] is here ... about 90 per cent of the Faroese are very pro-whaling all of a sudden. ... The food source isn't in [most peoples'] everyday life, and they generally think ... 'well now it's a discussion if I am Faroese or not.' 
Several respondents made the point that, away from Grindstop 2014, grindadráp is not a big part of Faroese life, many do not eat the meat often and participation in drives is spontaneous and voluntary and many either choose not to or are unable to take part. Indeed, one Faroese anti-whaler made the point that the main beneficiaries of the increased attention paid to grindadráp were the whalers who gained new members, new regulations and more political focus. One whaler agreed, stating that he had thought that his would be the last generation pilot whaling, but now his son was so angry at SSCS that he would also participate. Groups of people pulling together around whaling against outside interference have also been recorded in Iceland, Norway and the US (Brydon 1990; Mathisen 1996; van Ginkel 2004).

As noted earlier, Grindstop 2014 certainly gained a lot of attention in the Faroes. Within the SSCS ordering this was considered to be a positive occurrence: "[SSCS] have facilitated a debate among the people here on [grindadráp]" (West 2014). One Faroese publicly out against grindadráp agreed with this assertion, although he doubted it would have any long-term effect on what he saw as the inevitable decline of the practice. Indeed, Earthrace Conservation were able to take advantage of the situation to highlight their more conciliatory approach to SSCS, by bringing their founder, ex-SSCS member Pete Bethune, to the Faroe Islands where he engaged in a discussion with a PWA board member (Simonson 2014). However, despite this, Faroese anti-whalers were often negative about Grindstop 2014. A doctor responsible for much research on toxins in pilot whale meat stated that he felt SSCS complicated the issue and undermined his attempts to advise patients and the public "[b]ecause now they, more or less, feel that it's their duty to be a good Faroese." Likewise, a Faroese member of Earthrace asserted that considerable effort had been made in previous years to create a space where grindadráp and the issue of polluted whale meat could be discussed and the benefits and problems weighed. She felt that SSCS, by making whaling an issue of Faroese identity, are closing up that space and making it harder for them to gain ground in the public discourse. In support of this much of the discussion I encountered during Grindstop 2014 centered on SSCS itself, what SSCS' members did and said, and what the Faroese response should be. It was rare to hear discussion of the grindadráp's place in and value to Faroese society when not speaking directly to activists, suggesting that despite SSCS' efforts grindadráp remained unquestioned as integral to many orderings of Faroese-ness.

What many Faroese anti-whalers were articulating can be seen to be an alternative Faroese ordering of grindadráp. This ordering, as one Faroese activist put it, has developed from a combination of scientific information about poisons in pilot whale meat and introspection after a well-publicized, badlyconducted and long-lasting drive. This respondent and others stated that attitudes had begun to shift alongside an overall decline in pilot whale meat consumption (cf. Fielding 2010). However, respondents also stated that this shift had stalled following SSCS' campaign in 2011, with support for grindadráp resurgent. Within the Faroese anti-whaling ordering discussion is primarily around the suitability of pilot whale meat and blubber as a food resource - issues of animal welfare and the possible financial benefits of whale-based tourism are extant, but they are less prominent. Faroese anti-whalers draw on a body of information produced since the 1970s into the levels of PCBs, mercury and other toxins collecting in the meat and blubber of marine mammals (Joensen 2009). They highlight that pilot whale meat as 'traditional food' is effectively outside of ordinary food quality control systems and argue that if it were treated like other foods it would be considered unfit for human consumption. Indeed, they point out that since 2008 the Chief Medical Officer of the Faroes has publicly recommended that pilot whale meat should be discontinued from human consumption (Joensen 2009:283-285). ${ }^{15}$ Faroese anti-whalers argue for a cessation of grindadráp on the grounds that there will be health consequences for Faroese society in maintaining the practice, stating that the Faroese public do not understand how harmful pilot whale meat is. Respondents would link this discussion to broader debates about food production in the Faroe Islands, pointing out contradictory official positions on pilot whale meat and the confusing nature of the official guidelines (above). Most Faroese anti-whaling respondents articulating this position were distasteful of SSCS' methods and asserted that productive discussions had previously been on-going in Faroese society. This Faroese anti-whaling ordering overlaps considerably more with the FPW ordering than SSCS's. Indeed, by contesting the egalitarian basis of grindadráp (by pointing out the dangers of pilot whale meat $^{16}$ ) and by (presumably) avoiding eating pilot whale meat and blubber, Faroese anti-whalers present a

\footnotetext{
${ }^{15}$ Although the Faroese Food and Veterinary Authority has differed, suggesting adults could eat at most one meal of pilot whale meat and blubber per month (Heilsufrøðiliga starvsstovan 2011).

${ }^{16}$ SSCS do also argue that pilot whale meat is too toxic to eat, however FPW actors are able to assert that this is a local decision for Faroese people.
} 
very different challenge to grindadráp. In their rhetoric at least, FPW actors were welcoming of such discussions and, as such, it may be Faroese anti-whalers who represent a more substantive threat to pilot whaling (cf. Fielding 2010).

In conclusion, the events of Grindstop 2014 created and pitted two alternative orderings of grindadráp in the Faroe Islands. This gave the impression, reminiscent of huldufólk of legend, that two groups were inhabiting parallel and overlapping worlds. Exponents of both orderings had little desire to move together to enact a shared world, instead becoming more entrenched. Indeed, actions around Grindstop 2014 meant it was often actually impractical for the two sides to come together. As such, during the summer, the question of grindadráp became a trial of strength for both sides, the long-term consequence of which remains unclear. The conflict did reduce the prominence of a third ordering, that of Faroese people arguing for the reduction of and eventual ending of grindadráp. With energy and attention focused upon a struggle to enact either the SSCS or 'Faroese' position on pilot whaling, a more nuanced debate was largely suppressed. This debate, over the suitability of pilot whale meat as a food resource and its commensurate role in Faroese society, appeared to be on hold during Grindstop 2014. The true 'hidden people' of the political ontology of Grindstop 2014 were those Faroese who are not in favor of grindadráp. Similarly, how the marine environment has come to be polluted, who is responsible and what actions are possible is also largely hidden. ${ }^{17}$ Like other whaling conflicts, opinions on Faroese whaling polarized. The two opposing orderings became increasingly entrenched, with grindadráp gaining increased symbolic weight in Faroese society. In such circumstances, alternative orderings - without room for constructive interaction - were seldom visible. What ensued was a battle of wills, which will end only when one side is able to decisively enact its ordering (cf. Brox 2000). Rather than moving towards a common understanding of grindadráp, Grindstop 2014 seemed to move things further apart.

\section{References}

Av Rana, D. 2014. Sea Shepherd leggur nógv eftir seg í Føroyum. Sosialurin 110: 11.

Barsh, R.L. 2001. Food security, food hegemony, and charismatic animals. In R.L. Friedheim (ed.) Toward a sustainable whaling regime. Edmonton: Canadian Circumpolar Institute. Pp147-179.

Bertholdsen, Á. 2014a. Vilja tveita Sea Shepherd folk úr Føroyum. Sosialurin 102: 6.

Bertholdsen, Á. 2014b. Trý fólk frá Sea Shepherd handtikin. [accessed February 23 2015]. http://www.in.fo/news-detail/news/try-folk-fra-sea-shepherdhandtikin/?L=0oral.fo\&cHash=1242ae8aaa83972a23ea5d4ceb93b028.

Blaser, M. 2009. The threat of the Yrmo: the political ontology of a sustainable hunting program. American Anthropologist 111(1): 10-20.

Bloch, D. 2007. Pilot whales and the whale drive. Tórshavn: H.N. Jacobsens Bókahandil.

Blok, A. 2011. War of the whales: post-sovereign science and agonistic cosmopolitics in Japanese-global whaling assemblages science. Technology and Human Values 36(1): 55-81.

Blok, A. 2008. Contesting global norms: politics of identity in Japanese pro-whaling countermobilization. Global Environmental Politics 8(2): 39-66.

Brox, O. 2000. Schismogenesis in the wilderness: the reintroduction of predators in Norwegian forests. Ethnos 63(3): 387-404.

Brydon, A. 1990. Icelandic nationalism and the whaling issue. North Atlantic Studies 2(1-2): 185-191.

Bryman, A., 2004. Social research methods. 2nd edn. Oxford: Oxford University Press.

Bulliet, R. 2005. Hunters, herders, and hamburgers. New York: Columbia University Press.

Cannady, K. 2014. Dancing on the fissures: alternative senses of crisis in the Faroe Islands. In K. Lóftsdottir and L. Jensen (eds.) Crisis in the Nordic nations and beyond. Farnham: Ashgate. Pp87100.

De La Cadena, M. 2010. Indigenous cosmopolitics in the Andes: conceptual reflections beyond "politics." Cultural Anthropology 25(2): 334-370.

Epstein, C. 2008. Power of words in international relations: birth of an anti-whaling discourse. Cambridge, MA: MIT Press.

\footnotetext{
${ }^{17}$ Along with the suffering that pollution presumably causes pilot whales.
} 
Escobar, A. 1999. After nature: steps to an antiessentialist political ecology. Current Anthropology 40(1): $1-30$.

Fielding, R. 2010. Environmental change as a threat to the pilot whale hunt in the Faroe Islands. Polar Research 29(3): 430-438.

Fielding, R., J.E. Davis, Jr. and B.E. Singleton. 2015. Mutual aid, environmental policy, and the regulation of Faroese pilot whaling. Human Geography 10(3): 37-48.

Gaffin, D. 1996. In place: spatial and social order in a Faeroe Islands community. Prospect Heights, Illinois: Waveland Press.

Gaini, F. 2011. Cultural rhapsody in shift. In F. Gaini (ed.) Among the Islanders of the North. Tórshavn: Fróðskapur Faroe University Press. Pp132-162.

Gaini, F. 2013. Lessons of islands. Tórshavn: Fróðskapur Faroe University Press.

Gallup Føroyar. 2014. Gallupkanning vegna Prei. April 2014. Um grind. Gallup Føroyar.

van Ginkel, R., 2004. The Makah whale hunt and Leviathan's death: reinventing tradition and disputing authenticity in the age of modernity. Etnofoor 58-89.

Gregersen, Á. 2014. Sea Shepherd fekk nógva umtalu. Men sleppur ikki so lætt næta ár. Sosialurin 109: 6.

Hagstova Føroya. 2014. Census 2011: CS 8.2.1 Private households by availability of supplement food sources, boat, type of dwelling and household place of residence. [Accessed November 29]. http://www.hagstova.fo/en/statbank/census/2011/social-affairs/food-supplement.

Heilsufrøðiliga Starvsstovan. 2011. Dietary recommendation on the consumption of pilot whale meat and

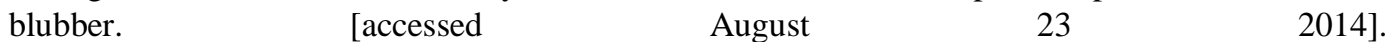
http://www.hfs.fo/pls/portal/docs/PAGE/HFS/WWW_HFS_FO/UMSITING/KUNNANDITILFA R/KUNNANDITILFARFRABODANIR/KUNNTILFFRAMATVORUR/GRIND-UK_0.PDF.

Heinesen, E.B. 2014. Cultural clashes make Sea Shepherd campaign counterproductive. The Arctic Journal. [accessed March 5 2015]. http://arcticjournal.com/opinion/914/cultural-clashes-make-seashepherd-campaign-counterproductive.

Ingold, T. 2003. Three in one: how an ecological approach can obviate the distinctions between body, mind and culture. In A. Roepstorff, N. Bubandt and K. Kull (eds.) Imagining nature. Aarhus: Aarhus University Press. Pp40-55.

Joensen, J.P. 2009. Pilot whaling in the Faroe Islands. Torshavn: Fróðskapur. Faroe University Press.

Kalland, A. 2009. Unveiling the whale: discourses on whales and whaling. Oxford/New York: Berghahn.

Kalland, A. 1993. Management by totemization: whale symbolism and the anti-whaling campaign. Arctic 46(2): 124-133.

Kendall, G. and G. Wickham. 2001. Understanding culture. London: Sage.

Kerins, S. 2010. A thousand years of whaling. Edmonton: CCI Press.

Klakstein, E. 2014. Vit eru ikki komin til Føroyar at berjast. Sosialurin 99: 8-9.

Kringvarp Føroya. 2014. Dagur \& vika. [accessed February 23 2015]. http://kvf.fo/netvarp/sv/2014/09/02/dagur-vika.

Latour, B. 2004. Whose cosmos, which cosmopolitics? Comments on the peace terms of Ulrich Beck. Common Knowledge 10(3): 450-462.

Law, J. 2004. After method: mess in social science research. London: Routledge.

Lindenskov, E. 2014a. Sea Shepherd bað politiið um hjálp. Sosialurin 86: 2.

Lindenskov, E. 2014b. Størri rok - meira kemur í kassan hjá Sea Shepherd. Sosialurin 93: 2.

Lindenskov, E. 2014c. Sjúrður skaale verjir grindadráp í Jyllandsposten. Sosialurin 94: 2.

Lindenskov, E. 2014d. Eg helt tú var Sea Shepherd. Sosialurin 97: 4.

Lindenskov, E. 2014f. Vit duga ikki at sannføra. Sosialurin 98: 2.

Lindenskov, E. 2014h. Mugu greiða frá grindadrápi. Sosialurin 100: 2.

Lögmansskrivstovan. 2014. Information memorandum. Community-based whaling in the Faroe Islands. [Accessed March 5 2015]. http://whaling.fo/Admin/Public/DWSDownload.aspx?File=\%2fFiles\%2fFiler\%2fwhaling\%2fINF O+MEMO+GRIND+OKT14.pdf. 
Mol, A. 1999. Ontological politics: a word and some questions. In J. Law and J. Hassard (eds.) Actor Network Theory and after. Oxford and Keele: Blackwell Publishers/The Sociological Review. Pp74-89.

Mathisen, S.R. 1996. "Real barbarians eat whales": Norwegian identity and the whaling issue. In P.J. Anttonen (ed.) Making Europe in Nordic contexts. Turku: Nordic Folklore Institute. Pp105-135.

Ministry of Fisheries. 2014. Catches 2000-2014. [accessed September 20 2014] http://www.whaling.fo/Default.aspx?ID=7125.

Nagtzaam, G.J. 2014. Gaia's Navy: The Sea Shepherd Conservation Society's battle to stay afloat and international law. William and Mary Environmental Law and Policy Review 38(3): 613-694.

Naurby, T. 1996. No nation is an island: language, culture and national identity in the Faroe Islands. Århus: SNAI-North Atlantic Publications.

North Atlantic Marine Mammal Commission. 1998. NAMMCO annual report 1997. Section 2 Management Committee. Tromsø: NAMMCO.

North Atlantic Marine Mammal Commission. 2012. NAMMCO Annual Report 2011. Tromsø: NAMMCO.

Nustad, K.G. 2011. Performing natures and land in the iSimangaliso wetland park, South Africa. Ethnos 76(1): 88-108.

Poulsen, L. 2014. Sea Shepherd ger gravsteinar. [Accessed February 19 2015]. http://www.in.fo/newsdetail/news/sea-shepherd-ger-gravsteinar/.

Olsen, D. 2014. Grind: vælmannað løgreglulið í Hvalba. [accessed February 232015 ]. http://www.in.fo/news-detail/news/grind-vaelmannad-loegreglulid-i-hvalba/.

Roepstorff, A. and N. Bubandt. 2003. General introduction: the critique of culture and the plurality of nature. In A. Roepstorff, N. Bubandt and K. Kull (eds.) Imagining nature. Aarhus: Aarhus University Press. Pp9-30.

Samró, H. 2014. Omma ræðist Sea Shepherd. Sosialurin 89: 29.

SSCS. 2014a. About the campaign. [accessed August 13 2014] http://www.seashepherd.org/grindstop/about-campaign/about-the-campaign.html.

SSCS. 2014b. The grind. [accessed October 1 2014]. http://www.seashepherd.org/grindstop/aboutcampaign/the-grind.html.

SSCS. 2014c. Sea Shepherd launches pilot whale defense campaign. Operation Grindstop 2014, at press conference in the Faroe Islands. [accessed September 17 2014]. http://www.seashepherd.org/newsand-media/2014/06/17/sea-shepherd-launches-pilot-whale-defense-campaign-operation-grindstop2014-at-press-conference-in-t-1597.

SSCS. 2014d. Sea Shepherd Conservation Society Announces Operation Grindstop 2014. [accessed December 24 2014]. https://www.youtube.com/watch?v=6hFVjxxSObQ.

SSCS. 2014e. Sea Shepherd crews brave nasty conditions to save an entire pod of whales in the Faroes. [accessed August 1 2014]. http://www.seashepherd.org/news-and-media/2014/08/01/seashepherd-crews-brave-nasty-conditions-to-save-an-entire-pod-of-whales-in-the-faroes-1609.

SSCS. 2014f. Operation GrindStop 2014: Press Conference with Pamela Anderson. [accessed December 4 2014]. https://www.youtube.com/watch?v=LwUQgJuqHzU.

SSCS, 2014g Operation Grindstop 2014: onshore command change. [accessed November 292015 ]. https://www.youtube.com/watch?v=wOuvNo3ToEk.

SSCS. 2014h. Operation GrindStop 2014: Sea Shepherd helps pilot whales back out to sea. [accessed December 21 2014]. https://www.youtube.com/watch?v=f5gkgxoSYZo.

SSCS. 2014i. Operation GrindStop 2014: volunteer voices. [accessed December 12014 ]. https://www.youtube.com/watch?v=4xzwIiho2NM.

SSCS. 2014j. 2014. Five beached bottlenose whales slaughtered by whale killers in the Faroe Islands. [accessed August 31 2014]. http://www.seashepherd.org/news-and-media/2014/08/29/fivebeached-bottlenose-whales-slaughtered-by-whale-killers-in-the-faroe-islands-1615.

SSCS. 2014k. Sea Shepherd crewmembers arrested for intervening against brutal Faroese pilot whale 'grind' hunt. [accessed August 31 2014]. http://www.seashepherd.org/news-and- 
media/2014/08/30/sea-shepherd-crewmembers-arrested-for-intervening-against-brutal-faroesepilot-whale-grind-hunt-1617.

SSCS. 2014l. 14 Sea Shepherd crewmembers released from custody today in the Faroe Islands. [accessed September 9 2014]. http://www.seashepherd.org/news-and-media/2014/08/31/14-sea-shepherdcrewmembers-released-from-custody-today-in-the-faroe-islands-1618.

SSCS. 2014m. Verdict handed down today in Faroese court for six Sea Shepherd volunteers who attempted to prevent slaughter of pilot whales. [accessed September 11 2014]. http://www.seashepherd.org/news-and-media/2014/09/08/verdict-handed-down-today-in-faroesecourt-for-six-sea-shepherd-volunteers-1623.

SSCS. 2014n. Operation Grindstop 2014: 14 crew arrested during grind. [accessed January 142014 ]. https://www.youtube.com/watch?v=0J4N9HPMD34.

Sea Shepherd UK. 2013. Sea Shepherd announces Operation GrindStop 2014: defending the whales and dolphins around the Faroe Islands. [accessed February $19 \quad 2015$ ]. http://www.seashepherd.org.uk/news-and-media/2013/09/09/sea-shepherd-announces-operationgrindstop-2014-1533.

Simonson, H. 2014. Sakligt tjak millum Bethune og Hermansen. [accessed March 132014 ]. http://www.in.fo/news-detail/news/sakligt-tjak-millum-bethune-oghermansen/?sword_list[]=pete\&sword_list[]=bethune\&no_cache=1.

Stuart, A., E.F. Thomas, N. Donaghue and A. Russell. 2013. "We may be pirates, but we are not protesters": identity in the Sea Shepherd Conservation Society. Political Psychology 34(5): 753777.

Taylor, B.L., R. Baird, J. Barlow, S.M. Dawson, J. Ford, J.G. Mead, G. Notarbartolo Di Sciara, P. Wade and R.L. Pitman. 2008. Globicephala melas. [accessed March 3 2015]. http://www.iucnredlist.org/details/9250/0.

Vágadal, T. 2014. Eg skammist at vera føroyingur. Sosialurin 94.

Vermeulen, E. 2014a. Links between the murderers in Taiji and the Faroe Islands. [accessed September 17 2014]. http://www.seashepherd.org/commentary-and-editorials/2014/03/06/links-between-themurderers-in-taiji-and-the-faroe-islands-635.

Vermeulen, E. 2014b, The Faroe Islands support commercial whaling. [accessed August 262014 ]. http://www.seashepherd.org/commentary-and-editorials/2014/08/19/the-faroe-islands-supportcommercial-whaling-663.

Vermeulen, E. 2014c. They slaughter dolphins, don't they? [accessed December 212014 ]. http://www.seashepherd.org/commentary-and-editorials/2014/11/06/they-slaughter-dolphins-dontthey-675.

Vermeulen, E. 2014d. The Cape Cod blackfisheries and a comparison with the Faroese grind. [accessed December 21 2014]. http://www.seashepherd.org/commentary-and-editorials/2014/12/05/the-capecod-blackfisheries-and-a-comparison-with-the-faroese-grind-678.

Viveiros de Castro, E. 2004. Perspectival anthropology and the method of controlled equivocation. Tipití: Journal of the Society for the Anthropology of Lowland South America 2(1): 3-20.

Wang, U.S. 2014. Position of the Government of the Faroes with regard to the Sea Shepherd Conservation Society. Personal communication.

Wang, Z. 2014. Sjóseyðamenn. Sosialurin 89: 28.

Watson, P. 2014a. Note to all the pro-whale murdering Sea Shepherd haters in the Faroe Islands. [accessed September 17 2014]. http://www.seashepherd.org/commentary-andeditorials/2014/07/07/note-to-all-the-pro-whale-murdering-sea-shepherd-haters-in-the-faroeislands-657.

Watson, P. 2014b. Captain Paul Watson responds to a pro-whaling Faroese editorial. [accessed August 26 2014]. http://www.seashepherd.org/commentary-and-editorials/2014/08/22/captain-paul-watsonresponds-to-a-pro-whaling-faroese-editorial-664.

West, S. 2014. Why are whales and dolphins killed in the Faroe Islands? [accessed September 172014 ]. http://www.seashepherd.org/commentary-and-editorials/2014/06/27/why-are-whales-anddolphins-killed-in-the-faroe-islands-655. 
Workman, M. 2014. Q\&A with Sea Shepherd. [accessed December 14 2014]. http://faroepodcast.blogspot.se/2014/10/podcast-225-q-with-sea-shepherd.html.

Wylie, J. 1987. The Faroe Islands. Lexington: University of Kentucky Press.

Wylie, J. and D. Margolin. 1981. The ring of dancers. Philadelphia: University of Pennsylvania Press. 